Relations industrielles

Industrial Relations

\title{
Unions and Legitimacy by Gary N. CHAISON and Barbara J. BIGELOW, Ithaca, N.Y.: ILR Press, 2002, 133 pp., ISBN 0-8014-3512-9.
}

\section{David Reynolds}

Volume 57, numéro 4, automne 2002

URI : https://id.erudit.org/iderudit/006913ar

DOI : https://doi.org/10.7202/006913ar

Aller au sommaire du numéro

\section{Éditeur(s)}

Département des relations industrielles de l’Université Laval

ISSN

0034-379X (imprimé)

1703-8138 (numérique)

Découvrir la revue

Citer ce compte rendu

Reynolds, D. (2002). Compte rendu de [Unions and Legitimacy by Gary N. CHAISON and Barbara J. BIGELOW, Ithaca, N.Y.: ILR Press, 2002, 133 pp., ISBN 0-8014-3512-9.] Relations industrielles / Industrial Relations, 57(4), 801-803. https://doi.org/10.7202/006913ar

Tous droits réservés @ Département des relations industrielles de l’Universite Laval, 2002
Ce document est protégé par la loi sur le droit d'auteur. L'utilisation des services d'Érudit (y compris la reproduction) est assujettie à sa politique d'utilisation que vous pouvez consulter en ligne.

https://apropos.erudit.org/fr/usagers/politique-dutilisation/ 


\section{Unions and Legitimacy}

by Gary N. ChAISON and Barbara J. BIgelow, Ithaca, N.Y.: ILR Press, 2002, 133 pp., ISBN 0-8014-3512-9.

Drawing from the field of organizational sociology, Gary Chaison and Barbara Bigelow offer the concept of legitimacy as a tool for both those who research and those who lead unions. As the authors summarize: "Our contribution is the use of the concept of legitimacy as a lens for seeing unions anew. Legitimacy provides a frame of reference for understanding the sources of union strengths and weaknesses. It enables us to understand why some strategies...have been successful while others... have not. And viewing unions in the context of legitimacy lets us see them both as organizations confined to certain avenues of activities by the widely shared expectations and values of constituencies and as organizations capable of managing legitimacy, that is, by changing the way they present themselves to conform to those expectations and values."

Chaison and Bigelow define three types of legitimacy. Pragmatic legitimacy stems from unions serving the direct material self-interest of their constituency. By contrast, unions gain moral legitimacy when they pursue goals of inherent social value-ones that are seen as "the right thing to do." Finally, with cognitive legitimacy, unions would be seen as an inevitable part of the social fabric in the same way as schools, churches, and hospitals are. Since the authors do not see unions as having cognitive legitimacy, the book focuses on the interplay between the pragmatic and moral dimensions.

Chaison and Bigelow offer five case studies. In the first two, the UPS strike and the Harvard Clerical Campaign, unions grew their goals of pragmatic concerns into messages for morale legitimacy. The Teamsters built solid membership support and broad public sympathy by publicizing their pragmatic demands for more full time jobs as a crusade against the involuntary part-time America. Similarly, union organizing among clerical and technical workers at Harvard succeeded only when activists moved beyond simply pitching unionization in terms of bread and butter bargaining gains to a moral effort to improve the quality of education and research by empowering would-be members. The authors contrast these successes with the failure of the AFLCIO's Associate Membership program. This effort sought to attract workers to the labour movement by offering a package of group benefits gained through a new category of membership. This narrow pragmatic appeal failed to offer either the bread and butter benefits of a real union or the moral attraction of joining a broader social movement. For Chaison and Bigelow, the contrast between the failures of associate membership and the initial Harvard organizing drives and the success of the Teamsters and the Harvard Unions of Clerical and Technical Workers illustrates the weakness of union reliance solely on pragmatic concerns. The Teamsters and HUCTW did not so much replace pragmatic legitimacy as they placed it in a broader framework that drew on the strength of moral appeal. As a result they increased their ability to deliver on the bread and butter concerns.

In the last two cases, unions also maintained their traditional role in protecting the pragmatic concerns of their members while developing campaigns with broad moral appeal. In the battle against the North American Free Trade Agreement, unions succeeded in allying with a wide range of community groups because union leaders linked worker issues with the pragmatic and moral concerns of these other groups. By making the battle against NAFTA a moral 
crusade, the labour movement gained key allies and notoriety despite ultimately losing the congressional vote. Similarly, the Massachusetts Nurses Association developed the Statewide Campaign for Safe Care to draw community support for their battle against increased mandatory overtime and the increasing substitution of unlicensed personnel for nurses. By defining themselves as defenders of quality care and as patient advocates s, their campaign gained the passage of several, but not all, proposed pieces of legislation. The publicity gained during the campaign also led to successes around these issues at the bargaining table and to the MNA's increased visibility and credibility among non-union nurses.

The concept of legitimacy also raises the important issue of who is the audience. The authors identify five possible constituencies for union legitimacy: the members, the public, non-union workers, employers, and coalition-partners. Chaison and Bigelow present findings from the literature that suggest that appeals among the first three are stable, encouraging, but also have limits. By contrast, legitimacy among employers has fallen dramatically in the past two decades. Legitimacy shows signs of recovery among would-be community allies. When combined with the five cases, the question of audience raises an interesting set of strategic issues as to whom unions are appealing and on what basis. Union activism becomes all the more difficult when the needs of legitimacy among one constituency conflict with the concerns of another. For example, civil rights demands for affirmative action can potentially conflict with union goals to protect seniority systems.

Unions and Legitimacy succeeds in illustrating the value of the concept of legitimacy for thinking about union strategy, success, and failure. The notion that pragmatic concerns are necessary, but not always sufficient for union success provides much room for debate and further research. The authors suggest that while many union members may see their union in pragmatic terms, those members most likely to be active in the union often draw on ideological and moral motivations. The authors also argue that moral legitimacy is a stronger bond both in broadening the union's constituency and mobilizing the membership. To a certain extent, unions can lose on their pragmatic gains, but win legitimacy gains when they "fight the good fight." Moral legitimacy, the authors argue, has to be constantly renewed, however. The notion of multiple constituencies with differing calculations for conferring legitimacy also raises a series of interesting dilemmas and possibilities for thinking about union strategy.

As a short work of one hundred pages, Unions and Legitimacy is more suggestive than conclusive. Clearly, the issues raised by the authors require far more research. The book is weak on counter examples. The associate membership case provides the only fully unsuccessful case. Yet, to fully understand the interplay between pragmatic and moral legitimacy requires examples of unions that confined themselves to pragmatic concerns. We would then need to know how such unions were not as successful or why they succeeded despite a lack of moral appeal. Are there changing economic and political conditions that are weakening exclusively pragmatic appeals? The Harvard organizing does provide a case of union lack of success when pursuing simply pragmatic legitimacy followed by success through adding moral dimensions. Yet, the book leaves readers wondering if the same comparison can not be made with the pre- and post-Carey Teamsters and the pre-NAFTA AFL-CIO coalition attempts. The contrasts between pragmatic and moral legitimacy run parallel with the notions of servicing and social unionism. Exploring this parallel and incorporating the literature around social 
unions would enrich the discussion of union legitimacy.

Some of the authors' claims require a more detailed explanation than their summary of the literature allows. The authors' proposition that moral legitimacy on a specific campaign does not carry over to moral legitimacy for unions in general seems overstated. In my research into labour-community coalitions, for example, activists from community groups have been drawn into battles framed on moral grounds only to change their view of unions as obsolete relics from the past to seeing unions as necessary partners in any progressive future. Chaison and Bigelow's literature review suggests a prevalence of pragmatic concerns among union members and non-members. Yet, the desire for respect and dignity is frequently articulated by workers as a central motivating drive when they organize unions. Furthermore, in the U.S. the AFL-CIO poll data suggests a steady growth of interest among non-union workers in joining a union from 30 percent in 1984, to 44 percent by 1996 , to over half today. What accounts for this seemingly rising legitimacy of unions among the general public? At an intuitive level, and as a labour educator, the way in which union members view and feel about their union seems more complex than simply pragmatic concerns. A more detailed and nuanced sense of this issue is certainly a subject for further research.

Prompting research questions and debate - not providing all the answersis precisely what the authors sought to achieve. The book's short length makes it quite accessible and a useful addition to the library of labour educators and researchers.

\section{DAVID ReYNoldS}

Wayne State University

\section{Working Time in Comparative Perspective, volume 1. Patterns, Trends, and the Policy Implications of Earnings Inequality and Unemployment}

sous la direction de Ging WoNG et Garnett PICOT, Kalamazoo, Mich. : W.E. Upjohn Institute for Employment Research, 2001, 387 p., ISBN 0-88099$227-1$.

Cet ouvrage est constitué d'une sélection de textes présentés à la conférence "Changes in Working Time in Canada and the United States », qui s'est tenu à Ottawa, les 13-15 juin 1996. Cette conférence avait été financée par le Canadian Employment Research Forum, Statistique Canada et le W.E. Upjohn Institute for Employment Research, ce dernier étant l'éditeur des actes. Elle se situait, nous dit-on, dans la continuité de la publication d'un rapport d'une commission parlementaire sur la réforme de la sécurité sociale, en février 1995. Ce rapport indiquait que toute réforme de la sécurité sociale devait tenir compte de l'évolution des formes d'emploi et horaires de travail. La conférence avait pour but de réunir des analyses de l'évolution des formes d'emploi précaires, flexibles et autres, ainsi que du temps de travail, et de comparer la situation avec celle des États-Unis, dans quelques cas aussi avec l'Australie et l'Europe. On peut noter que la publication de l'ouvrage de Jeremy Rifkin sur « La fin du travail » (The End of Work, 1995) avait aussi considérablement accru l'intérêt pour les questions de temps de travail et de formes d'emploi au milieu de la décennie 1990.

La critique première qu'il faut adresser à ce livre, c'est le fait que les données statistiques datent quelque peu... puisque la conférence a eu lieu en 1996 ; ceci est regrettable, car les analyses qui y sont présentées ne manquent pas du tout d'intérêt. Toutefois, au terme de la lecture de cet ouvrage fort volumineux 